\title{
Microbial Loads and Physicochemical Characteristics of Fruits from Four Saudi Date Palm Tree Cultivars: Conformity with Applicable Date Standards
}

\author{
Salah M. Aleid ${ }^{1 *}$, Bakri H. Hassan ${ }^{2}$, Salah A. Almaiman ${ }^{3}$, Safar H. Al-Kahtani ${ }^{2}$, Sobhy M. Ismail ${ }^{2}$ \\ ${ }^{1}$ Date Palm Research Center of Excellence, King Faisal University, Alahsa, Saudi Arabia; ${ }^{2}$ College of Food and Agriculture Sciences, \\ King Saud University, Riyadh, Saudi Arabia; ${ }^{3}$ Department of Food Science and Nutrition, King Saud University, Riyadh, Saudi Ara- \\ bia. \\ Email: "seid@kfu.edu.sa
}

Received November $19^{\text {th }}, 2013$; revised December $19^{\text {th }}, 2013$; accepted December $26^{\text {th }}, 2013$

Copyright (c) 2014 Salah M. Aleid et al. This is an open access article distributed under the Creative Commons Attribution License, which permits unrestricted use, distribution, and reproduction in any medium, provided the original work is properly cited. In accordance of the Creative Commons Attribution License all Copyrights (C) 2014 are reserved for SCIRP and the owner of the intellectual property Salah M. Aleid et al. All Copyright (C) 2014 are guarded by law and by SCIRP as a guardian.

\section{ABSTRACT}

The conformity of Saudi dates cultivars to date standards has not been studied extensively. In this study, microbial loads and physicochemical characteristics of four Saudi date cultivars (Sukkary, Khalas, Sugai and Anbara) were determined. Anbara cultivar had significantly higher mould and yeast counts than recommended under Saudi technical regulation and standards for packaged whole dates. Moisture content and insect damage for all studied cultivars fell within Codex standards. Single fruit weight for pitted and unpitted dates was higher than recommended under international standards. Date cultivar had a significant effect on fruit color thus fruit color should be included in Saudi technical regulation and standards for date grading.

\section{KEYWORDS}

Saudi Dates; Standards; Microbial Load; Physicochemical Characteristics

\section{Introduction}

The global production of fruit from the date palm tree (Phoenix dactylifera L.) was estimated at 7.75 million tons worth US \$3.82 billion in 2010 (FAOSTAT, 2012). Saudi Arabia is ranked as the second largest date producer in the world after Egypt, with an annual production of 1.078 million tons of dates produced from over 24 million date palm trees (FAOSTAT, 2012; Ministry of Agriculture, 2011). Palm dates are the most widely grown fruit in the Kingdom of Saudi Arabia. Understanding the physicochemical, biochemical and microbiological characteristics of date palm tree cultivars is considered necessary for better utilization of dates. Physicochemical analyses of dates have carried out in many countries such as Iraq, Iran, Saudi Arabia, Egypt, Sudan, Algeria and Tunisia [1,2]. Chemical composition and the quality of dates vary widely with cultivars and are close-

\footnotetext{
*Corresponding author.
}

ly related to farming and climatic conditions as well as to pre- and post-harvest practices. Nearly 2000 cultivars of date palm are known worldwide, but not all of them have been evaluated for their performance and fruit quality [3].

Fourteen native date cultivars from different oases and regions of Morocco, Tunisia and Algeria were examined for their approximate composition, water activity, and CIELAB parameters $[2,4,5]$. The results showed that sugars were the predominant component in all studied date cultivars (54.14 - $75.56 \mathrm{~g} / 100 \mathrm{~g} \mathrm{DM}$ ), followed by moisture content $(7.2 \%$ - 31.9\%), along with small amounts of protein (1.9 - $3.3 \mathrm{~g} / 100 \mathrm{~g} \mathrm{DM})$, fat (0.1 - 0.44 g/100g DM), and ash (1.88 - 3.45 g/100g DM). Early maturing dates had the highest water activity $(0.78-0.87)$ in contrast to late maturing dates cultivars. In the Deglet Nour (Tunisia) and Aziza bouzid (Morocco) cultivars, sucrose is dominant, whereas, the majority of other cultivars were rich in fructose and glucose in comparable proportions. All cultivars show significant differences in 
color [4].

Date palm fruit from 11 Tunisian cultivars were analyzed for their main chemical components [5]. Results showed that date fruits were rich in sugar (79.93 - 88.02 $\mathrm{g} / 100 \mathrm{~g}$ DM), fiber (8.09 - $20.25 \mathrm{~g} / 100 \mathrm{~g} \mathrm{DM})$ and ash (1.73 - $2.59 \mathrm{~g} / 100 \mathrm{~g} \mathrm{DM})$. The mineral fraction was dominated by potassium and the sugar fraction by reducing sugars (glucose, fructose) with the exception of Deglet Nour, Kentichi, and Bajo cultivars, which were rich in sucrose [5].

The Kingdom of Saudi Arabia produces surplus dates that can be sold in the export market. In order to standardize quality across the major date cultivars in the Kingdom, Abdoulhadi et al. [6] ascertained fruit characteristics of dates (Tamar stage) from Khalas, Sheshi, and Reziz cultivars. Fruit weight (g), size of fruit (length and width), number of fruits per $500 \mathrm{~g}$ of dates, fruit moisture, color, and texture were determined. Khalas recorded the maximum fruit length in all the three categories of large, medium and small-sized fruits. The cultivar Khalas had the least fruit moisture and the highest mean color differences $(\Delta \mathrm{E})$, indicating light color (yellow) fruits [6].

Quality standards of dates must include chemical, physical and sensory attributes. Date varieties significantly vary in terms of their chemical composition. The variation in chemical composition affects the structural, sensory and textural properties of fruits [7]. The function of sensory analysis is to provide measurements that are accurate, precise, and valid [8]. Variation in sensory attributes is due to the genetic differences and variable growth conditions. Dates show, perhaps more than other fruits, wide variations in their final appearance and quality. With respect to consumers, the important quality criteria of a produce are appearance (including color, size, and shape, condition and absence of defects), mouth feel or texture, flavor, and nutritional value [9].

A number of countries have formulated and applied date standards at the national level both for locally produced and imported dates. In an effort to create global standards for dates, the Codex Alimentarius Commission of the joint FAO/WHO Food Standards Program formulated a proposal for date standards for world-wide application, subject to the acceptance by the respective governments [10]. There are many date standards that include both local and international specifications. Some of these standards are: the United States standards for grades of dates (1955), Codex standards for dates (Codex CTAN, 143-1985), UNECE standards for marketing and commercial quality control of whole dates, Saudi standards for packaged dates No.543/1989, Gulf Countries standard No.656-1997, and the recent Gulf standard organization (GSO) technical regulation for prepackaged whole dates No.656-2010. The current standards (i.e.,
Codex, US standards, Saudi standards, Gulf countries standards) for dates were developed to define characteristic features of some varieties of date fruits. They contributed to the ease of global trade for dates. However, the standards do not emphasize some important quality parameters of these fruits. There are no extensive studies on the quality indices and standards for the most abundant and commercially important date palm fruits (Sukkary, Khalas, Sugai and Anbara) in Saudi Arabia. Therefore, this study is designed to assess quality indices (physico-chemical and microbial evaluation) of Sukkary, Khalas, Sugai and Anbaradate cultivars. Results from this work can be used to determine if the quality of these dates fall within the recommended standards.

\section{Materials and Methods}

\subsection{Sampling}

Four popular, economically important Saudi dates were procured from regional date markets. The date cultivars were; Sukkary (Qassim region), Khalas (Al-Hassa), Sugai (Riyadh region), and Anbara Al-Madina (Al-Madina Al-Munawarah). Typical morphological image for the experimental cultivars is shown in (Figure 1). The fruits were produced in the 2010 date season. Samples were cleaned, washed and packaged in polyethylene bags, inside $3 \mathrm{~kg}$ cartons, and preserved in a refrigerator at $5^{\circ} \mathrm{C}$ until experimental tests were performed. All date cultivars were manually sorted into three size classes (large, medium, and small) according to their individual fruit volume. The classification of fruit size, by weight, is defined for each cultivar in Table 1.

A $3 \times 3$ factorial treatment design was employed with three fruit sizes (large, medium, and small), and three processing techniques (unpressed-unpitted, pressed-pitted, unpressed-pitted). The term "pressed" refers to dates that were compressed into layers by mechanical force, whereas "unpressed" refers to dates that were packaged without mechanical force or compression. Pressing of whole dates was made by packaging in flexible sealed

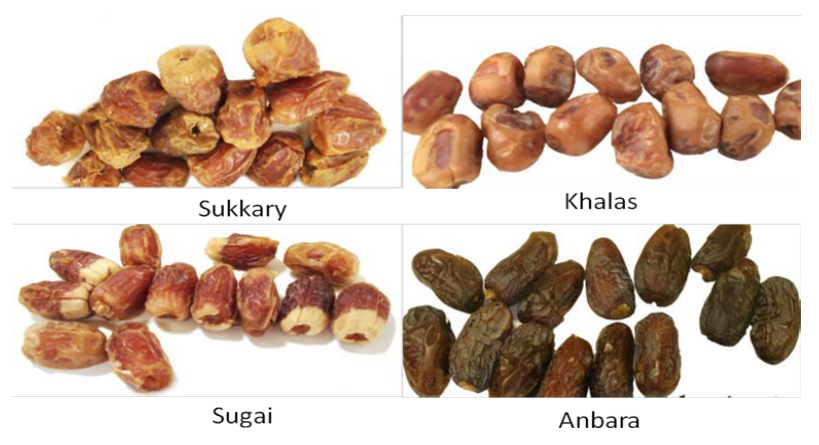

Figure 1. Typical morphological image for experimental Saudi date cultivars (Sukkary, Khalas, Sugai and Anbara). 
Table 1. Classification of date palm fruits from four different cultivars into three size classes (large, medium, and small) according to weight (g).

\begin{tabular}{ccccc}
\hline \multirow{2}{*}{ Class } & \multicolumn{5}{c}{ Cultivar } \\
\cline { 2 - 5 } & Sukkary & Khalas & Sugai & Anbara \\
\hline Large & 14 & 12 & 15 & 20 \\
Medium & 11 & 10 & 12 & 16 \\
Small & 9 & 8 & 9 & 12 \\
\hline
\end{tabular}

polyethylene-polyamide (PE-PA) bags under vacuum using J-V012 Heavy Duty Double Chambers Vacuum Packaging Machine (Jaw Feng Machinery Co., Ltd. Shang Hsiang, Chia Yi County, Taiwan). The term "pitted" refers to date fruits whose seeds were removed. Hand pitting of whole dates involved cutting the side of date fruit from end to end using a sharp knife in order to remove the pit.

As a result, there were 9 samples from each date cultivar and a total number of 36 samples. Variables measured in this study included microbial loads (total bacteria, moulds and yeasts, and coliforms counts), physico-chemical characteristics (moisture, sugars, water activity, color, weight, length and width of date fruits and pits), and the number of date fruits per $500 \mathrm{~g}$ of dates. Five fruits from each of the nine treatments were randomly selected for each quality assessment.

\subsection{Chemical Analysis}

Moisture content was determined according to AOAC methods [11]. Moisture (g water/100g sample) was determined by drying a $5 \mathrm{~g}$ sample under vacuum at $70^{\circ} \mathrm{C}$ to constant weight and moisture was calculated as $\mathrm{g}$ water/100g sample. Sucrose, glucose, and fructose were determined using High Performance Liquid Chromatography (HPLC) as follows: Triplicate $5 \mathrm{~g}$ date syrup samples were weighed into a $50 \mathrm{ml}$ volumetric flask and the volume was topped-up to $50 \mathrm{ml}$ using distilled water. The samples were homogenized for $2 \mathrm{~min}$. The mixtures were filtered and the filter papers were washed with extra 10 $\mathrm{ml}$ distilled water. From the filtered extracts, $20 \mu \mathrm{L}$ injection volumes were used. The extracts were analyzed on Varian HPLC (Varian, Walnut Creek, CA, USA) equipped with RID 6A refractive index detector (Shimadzu, Columbia, MD, USA) and Varian Star 6 Chromatography Workstation software. A carbohydrate column was used for the separation of sugars using the eluent HPLC-grade acetonitrate/water mixture in the ratio of $86: 14$. The flow rate was adjusted to $0.2 \mathrm{ml} / \mathrm{min}$. The peaks from the recorder were compared with peaks from a standard water solution of glucose/fructose/sucrose (Sigma-Aldrich Co., St. Louis, MO, USA). Peaks were identified by comparing retention times with sugar standards. The respective peak areas were used for the quantitative analysis. Calibration curves for each sugar were prepared at six levels, ranging from 0.1 to $20 \mathrm{~g} \mathrm{~L}^{-1}$ for sucrose, glucose and fructose, all dissolved in ultra-pure water [12].

\subsection{Physicochemical Analysis}

Water activity (aw) was determined according to AOAC method number 978.18 [11], using an AquaLab apparatus (Decagon Devices, Inc. Pullman, Washington 99163). Color measurements for the fruit were obtained using a Hunterlab Color Quest-45/0 LAV color difference meter (Hunter Associates Laboratory, Inc., USA) standardized with black and green tiles. Measured parameters were the degree of lightness (L) with an $\mathrm{L}$ value of 100 representing white, $L$ value of zero representing black, positive "a" values representing redness, and negative "b" values representing yellowness. Measurements were conducted on ten individual fruits per replicate [13].

\subsection{Weight, Length and Width of Date Fruits}

Date fruit weight was estimated using a sensitive balance Model 204 (Metter, Toledo, Switzerland) with sensitivity of $0.1 \mathrm{mg}$. Length and width of both date fruits and stones were measured using Absolute Digimatic digital electronic vernier caliper of readability $0.00 \mathrm{~mm}$ (Model CD-15CW, Mitutoyo Corporation, Japan). The length is defined as the longest dimension in the direction parallel to the fruit stem, while the major diameter is the maximum dimension perpendicular to the stem.

\subsection{Microbiological Analysis}

Aerobic mesophilic bacteria were counted on Plate Count Agar (PCA Oxoid, CM0325) dishes using the pour plate method. The plates were incubated at $30^{\circ} \mathrm{C}$ for 2 to 3 days and the counts expressed as colony forming units per $\mathrm{g}$ or $\mathrm{ml}$ (cfu/g or cfu/ml) of the sample. Date samples were aseptically destoned using sterile forceps and microbial loads calculated for the flesh. Flesh samples (10 g) were weighed into sterile stomacher bags, to which 90 $\mathrm{mL}$ of sterile peptone water (Oxoid, CM0009) was added. The mixture was homogenized in a stomacher (LabBlender 400, Seward Medical, England) for 45 seconds and aliquots $(1.0$ or $0.1 \mathrm{~mL}$ ) plated out in duplicate as $10-$ fold dilutions in peptone water. Aerobic mesophilic bacteria were cultured on Plate Count Agar dishes (PCA Oxoid, CM0325) using the pour plate method. The plates were incubated at $30^{\circ} \mathrm{C}$ for 2 to 3 days and the counts expressed as colony forming units per $\mathrm{g}$ or $\mathrm{ml}$ (cfu/g or $\mathrm{cfu} / \mathrm{ml}$ ) of the sample. Coliforms were counted on Violet Red Bile Agar (VRBA Oxoid, CM0107) using the pour 
plate/overlay method. The plates were incubated at $37^{\circ} \mathrm{C}$ for 24 - 48 hours. Round, purple-red colonies $(0.5$ - 2 $\mathrm{mm}$ diameter) surrounded by purple-red haloes on VRBA plates were counted as coliforms. Yeasts and moulds were cultured on Potato Dextrose Agar plates (PDA Oxoid, CM0139) using the spread plate method. Yeasts were incubated at $30^{\circ} \mathrm{C}$ for 3 days, and moulds at $20^{\circ} \mathrm{C}$ $30^{\circ} \mathrm{C}$ for 3 to 7 days and the counts were expressed as $\mathrm{cfu} / \mathrm{g}$ or $\mathrm{cfu} / \mathrm{ml}$ of the sample [14].

\subsection{Experimental Design and Statistical Analysis}

A $3 \times 3$ factorial treatment arrangement was employed with three fruit sizes, and three processing treatments as main factors. A randomized block design was used to run the experiments. Analysis of variance of the data collected during the course of each trial was performed. Analysis of Variance (ANOVA) was performed to estimate the interaction effect among the main factors using SAS software (Ver. 6.02). Duncan's multiple-range test $(\mathrm{P} \leq 0.05)$ was used to compare treatments means [15].

\section{Results and Discussion}

Reported results are means of three replicates from three sub-samples (five individual fruits per sample).

\subsection{Microbial Loads of Dates}

Results presented in Table 2 show microbial loads of unpressed-unpitted date fruits from the studied cultivars. The results indicate that mesophilic aerobic bacteria, moulds and yeasts, and coliform loads ranged from 20 $2.1 \times 10^{3}, 0.0-900$, and $0.0-1.2 \times 10^{2} \mathrm{cfu} / \mathrm{g}$, respectively. These microbial numbers fall within the acceptable limits according to Saudi standards and GSO technical regulation for prepackaged whole dates. The only exception was in the medium-sized fruits of Khalas cultivar which had unacceptable load of coliforms (120 cfu/g). Nussinovitch et al. [16] reported colony counts of soft dates in the Tamr stage of the order of $10^{4} \mathrm{cfu} / \mathrm{g}$ lactic acid bacteria. Aidoo et al. [17] found bacteria, coliforms and moulds to be contaminants of dates (Tamr) purchased in stores within Greater Glasgow. Kader [18] reported that microbial spoilage of dates (Tamr) can be caused by yeasts, moulds and bacteria. Spoilage can be controlled by drying the dates to $20 \%$ moisture or lower and by maintaining the recommended temperature and relative humidity ranges throughout the handling system. According to Public Health Laboratory Services (PHLS)

Table 2. Microbial loads of unpressed-unpitted dates fromfour different cultivars.

\begin{tabular}{|c|c|c|c|c|}
\hline Date cultivar & Fruit size & Mesophilic aerobic bacteria (cfu/g) & Moulds and yeast (cfu/g) & Coliform VRBA (cfu/g) \\
\hline \multirow{4}{*}{ Sukkary } & Large & $20.3 \mathrm{~b}$ & $0.0 \mathrm{~b}$ & $0.0 \mathrm{~b}$ \\
\hline & Medium & $50.0 \mathrm{~b}$ & $0.0 \mathrm{~b}$ & $0.0 \mathrm{~b}$ \\
\hline & Small & $1016.0 \mathrm{a}$ & $50.0 \mathrm{a}$ & $0.0 \mathrm{~b}$ \\
\hline & LSD (5\%) & 44.9 & 28.9 & - \\
\hline \multirow{4}{*}{ Khalas } & Large & $1000.0 \mathrm{~b}$ & $400.7 \mathrm{~b}$ & $0.0 \mathrm{~b}$ \\
\hline & Medium & $2100.0 \mathrm{a}$ & $775.0 \mathrm{a}$ & $120.0 \mathrm{a}$ \\
\hline & Small & $1275.0 \mathrm{ab}$ & $175.0 \mathrm{c}$ & $0.0 \mathrm{~b}$ \\
\hline & LSD (5\%) & 839.3 & 88.2 & 39.8 \\
\hline \multirow{4}{*}{ Sugai } & Large & $450.0 \mathrm{a}$ & $150.0 \mathrm{a}$ & $0.0 \mathrm{~b}$ \\
\hline & Medium & $53.3 \mathrm{~b}$ & $0.0 \mathrm{~b}$ & $0.0 \mathrm{~b}$ \\
\hline & Small & $50.0 \mathrm{~b}$ & $25.0 \mathrm{~b}$ & $0.0 \mathrm{~b}$ \\
\hline & LSD (5\%) & 129.8 & 48.4 & - \\
\hline \multirow{4}{*}{ Anbara } & Large & $30.0 \mathrm{c}$ & $750.0 \mathrm{a}$ & $0.0 \mathrm{~b}$ \\
\hline & Medium & $155.0 \mathrm{a}$ & $100.0 \mathrm{~b}$ & $0.0 \mathrm{~b}$ \\
\hline & Small & $100.0 \mathrm{~b}$ & $900.0 \mathrm{a}$ & $0.0 \mathrm{~b}$ \\
\hline & LSD (5\%) & 47.5 & 179.0 & - \\
\hline
\end{tabular}

Means in each column followed by the same letter(s) do not differ at $\mathrm{P} \leq 0.05$ according to Duncan's multiple-range test. Values represent the mean \pm standard deviation $(\mathrm{n} \sim 5)$ for each fruit size. 
$[19,20]$ in the United Kingdom, aerobic colony counts of more than $10^{7} \mathrm{CFU} / \mathrm{g}$ in fresh fruits exceed the aerobic colony counts guideline, which should necessitate further inspection of the premises concerned to determine whether hygiene practices for food production or handling are adequate or not [21].

There was wide variation in the microbial loads among studied cultivars. The small-sized fruits of Sukkary cultivar showed significantly $(\mathrm{P} \leq 0.05)$ higher counts for mesophilic aerobic bacteria and mould and yeasts than the larger or medium-sized fruits. Medium size Khalas fruits showed significantly $(\mathrm{P} \leq 0.05)$ higher mesophilic aerobic bacteria and moulds and yeast counts. However, the large-sized fruits of Sugai cultivar had significantly $(P \leq 0.05)$ higher load of these microbial groups. In the case of Anbara cultivar, the medium size fruits had significantly $(\mathrm{P} \leq 0.05)$ higher number for mesophilic aerobic bacteria, while the small size fruits had significantly higher moulds and yeasts counts. Elevated counts of mesophilic aerobic bacteria may be due to inadequate processing or post-processing contamination such as poor dates handling or hygiene practices. Abu-Zinada and Ali [22] reported fungi contamination of different date (Tamr) varieties. Nussinovitch et al. [16] reported yeasts colony counts of soft dates in the Tamr stage of the order $10^{2}$ $\mathrm{cfu} / \mathrm{g}$.

Fresh dates normally carry natural non-pathogenic epiphytic microorganisms, but during growth, harvest, transportation, and further handling dates can be contaminated with pathogens from animal and human sources. As dates are eaten without further processing, microbial contamination may represent a health risk for consumers, and therefore a food safety problem [23-25].

Table 3 shows the microbial loads of the pressed-unpitted date fruits packaged under vacuum. It was observed that total mesophilic aerobic bacteria and total moulds and yeasts counts ranged from $10-500$ and from $1 \times 10^{2}-1.8 \times 10^{4} \mathrm{cfu} / \mathrm{g}$, respectively. Mesophilic aerobic bacteria are not considered an important potential spoilage agent of date fruits, but their presence is regarded as an index for the hygienic status of the fruits. El-Sherbeeny et al. [26] detected Staphylococcus aureus and aerobic colony counts of $6.3 \times 10^{5} \mathrm{cfu} / \mathrm{g}$ in loose dates. The yeasts and moulds load is higher than that recommended by Saudi standards for packaged dates. Yeasts and moulds are considered to be important spoilage agents of date fruits. According to Saudi standard for microbiological criteria of foods, the loads of yeasts in date fruits should not exceed $10 \mathrm{cfu} / \mathrm{g}$ in 3 out of 5 replicates of tested sample and that of moulds not to exceed $10^{2} \mathrm{cfu} / \mathrm{g}$ in 3 of 5 replicates of tested sample (SASO) [27]. Concerning total coliforms, the studied samples showed counts that ranged from $10-200 \mathrm{cfu} / \mathrm{g}$.
Table 3. Microbial loads of pressed-unpitted dates from four different cultivars.

\begin{tabular}{ccccc}
\hline $\begin{array}{c}\text { Date } \\
\text { cultivar }\end{array}$ & Fruit size & $\begin{array}{c}\text { Mesophilic aerobic } \\
\text { bacteria (cfu/g) }\end{array}$ & $\begin{array}{c}\text { Moulds and } \\
\text { Yeast (cfu/g) }\end{array}$ & $\begin{array}{c}\text { Coliform } \\
\text { VRBA (cfu/g) }\end{array}$ \\
\hline \multirow{2}{*}{ Sukkary } & Large & $200.0 \mathrm{~b}$ & $1000.0 \mathrm{~b}$ & $20.0 \mathrm{~b}$ \\
& Medium & $200.0 \mathrm{~b}$ & $1000.0 \mathrm{~b}$ & $10.0 \mathrm{c}$ \\
& Small & $500.0 \mathrm{a}$ & $7000.0 \mathrm{a}$ & $40.0 \mathrm{a}$ \\
& LSD (5\%) & 35.1 & 1686.0 & 6.9 \\
& Large & $333.3 \mathrm{ab}$ & $7000.0 \mathrm{~b}$ & $10.0 \mathrm{~b}$ \\
Khalas & Medium & $400.0 \mathrm{a}$ & $8000.0 \mathrm{~b}$ & $50.0 \mathrm{~b}$ \\
& Small & $300.0 \mathrm{~b}$ & $11000.0 \mathrm{a}$ & $900.0 \mathrm{a}$ \\
& LSD (5\%) & 67.1 & 1173.0 & 52.0 \\
& Large & $450.0 \mathrm{a}$ & $18000.0 \mathrm{a}$ & $920.0 \mathrm{a}$ \\
Sugai & Medium & $11.0 \mathrm{c}$ & $3000.0 \mathrm{c}$ & $620.0 \mathrm{~b}$ \\
& Small & $300.0 \mathrm{~b}$ & $300.0 \mathrm{c}$ & $570.0 \mathrm{~b}$ \\
& LSD (5\%) & 117.2 & 1994.0 & 186.9 \\
& Large & $10.0 \mathrm{c}$ & $3000.0 \mathrm{a}$ & $410 \mathrm{a}$ \\
Anbara & Medium & $200.0 \mathrm{a}$ & $2000.0 \mathrm{~b}$ & $280.0 \mathrm{~b}$ \\
& Small & $100.0 \mathrm{~b}$ & $3000.0 \mathrm{a}$ & $170.0 \mathrm{~b}$ \\
& LSD (5\%) & 67.9 & 652.9 & 111.6 \\
\hline
\end{tabular}

Means in each column followed by the same letter(s) do not differ at $\mathrm{P} \leq$ 0.05 according to Duncan's multiple-range test. Values represent the mean \pm standard deviation $(\mathrm{n} \sim 5)$ for each fruit size.

Coliforms are not included in the Saudi standards for date fruits, but their presence is an index of possible recent contamination with human feces. Data also indicate that the small size fruits of Sukkary, Khalas and Anbara cultivars had significantly $(\mathrm{P} \leq 0.05)$ higher mesophilic aerobic bacteria loads than the other fruit sizes of the same cultivars. However the large size fruits of the Sugai cultivars showed the highest $(\mathrm{P} \leq 0.05)$ microbial loads than other fruit sizes of the same cultivar. The variation in the microbial load among studied cultivars and sizes might be due to differences in farm management practices. The source of those microorganisms was probably the farm environment, different handling practices, and sanitary conditions of the marketing area. However, the presence of fecal coliforms in fresh fruits or vegetables may not be an indication of fecal contamination since some genera of bacteria in the fecal coliform group are from non-fecal sources in the environment [28].

Table 4 summarizes the microbial load for the unpressed-pitted date samples. Total bacterial, moulds and yeasts, and coliform counts ranged from $20-1.2 \times 10^{2}$ $\mathrm{cfu} / \mathrm{g}, 0.0-3.5 \times 10^{2} \mathrm{cfu} / \mathrm{g}, 0.0-25 \mathrm{cfu} / \mathrm{g}$, respectively. From these results it could be observed that moulds and 
Table 4. Microbial loads of unpressed-pitted dates from four different cultivars.

\begin{tabular}{cccc}
\hline Date cultivar & $\begin{array}{c}\text { Mesophilic aerobic } \\
\text { bacteria (cfu/g) }\end{array}$ & $\begin{array}{c}\text { Moulds and } \\
\text { Yeast (cfu/g) }\end{array}$ & $\begin{array}{c}\text { Coliform VRBA } \\
\text { (cfu/g) }\end{array}$ \\
\hline Sukkary & $20.0 \mathrm{~b}$ & $0.0 \mathrm{c}$ & $0.0 \mathrm{c}$ \\
Khalas & $100.0 \mathrm{a}$ & $175.0 \mathrm{~b}$ & $5.0 \mathrm{~b}$ \\
Sugai & $110.0 \mathrm{a}$ & $0.0 \mathrm{c}$ & $25.0 \mathrm{a}$ \\
Anbara & $20.0 \mathrm{~b}$ & $350.0 \mathrm{a}$ & $0.0 \mathrm{c}$ \\
LSD (5\%) & 25.3 & 37.5 & 1.9 \\
\hline
\end{tabular}

Means in each column followed by the same letter(s) do not differ at $\mathrm{P} \leq$ 0.05 according to Duncan's multiple-range test. Values represent the mean \pm standard deviation $(\mathrm{n} \sim 5)$ for each cultivar.

yeasts counts on Anbara dates were higher than recommendations in the Saudi standards for packaged dates. Moreover Khalas, Sugai and Anbara dates showed unacceptable levels of coliform bacteria according to Public Health Laboratory Services (PHLS) [19,20]. More than $10^{2} \mathrm{CFU} / \mathrm{g}$ coliform represents a potential risk to health. Counts at this level may also indicate a significant failure of hygiene standards in the handling and/or storage of ready to eat foods like fresh fruits and dates.

Data also indicated that Khalas and Sugai fruits had significantly ( $\mathrm{P} \leq 0.05)$ higher total bacterial counts compared to fruits from the other cultivars. Anbara fruits had significantly $(\mathrm{P} \leq 0.05)$ higher moulds and yeasts counts compared to fruits from the other cultivars. Sugai fruits had significantly $(\mathrm{P} \leq 0.05)$ higher coliform counts than other cultivars. These results indicated that there was a wide variation in the microbial loads of the date fruits between the cultivars, fruit sizes and processing techniques. The total bacterial and moulds and yeasts counts in the studied samples were higher than those found in previous studies of microbial loads in date fruits $[16,17]$. According to Saudi standards for packaged dates, the maximum counts for yeasts, moulds, and coliforms should be $210 \mathrm{cfu} / \mathrm{g}, 310 \mathrm{cfu} / \mathrm{g}$ and $10 \mathrm{cfu} / \mathrm{g}$, respectively, but there are no limits for other microbial groups. A new yeast load level of 10 - $100 \mathrm{cfu} / \mathrm{g}$ should be included in the Saudi standard. However, the acceptable counts of yeasts and mouldscould be compared with guidelines such as the Woolworths Quality Assurance Standard (WQAS) where counts greater than $1000 \mathrm{cfu} / \mathrm{g}$ in fresh fruits is considered unsatisfactory [29].

\subsection{Sugar Contents}

The content of glucose and fructose (mono-saccharides) as well as sucrose (disaccharide) in the studied date cultivars was determined and presented in Table 5. In the GSO technical regulation for prepackaged whole dates, article 4 classifies dates according to type of sugars.
Table 5. Sugar content (g/100g date flesh) of unpressedunpitted dates.

\begin{tabular}{ccccc}
\hline Date cultivar & Glucose & Fructose & Sucrose & Total \\
\hline Sukkary & $7.3 \mathrm{c}$ & $7.1 \mathrm{~b}$ & $49.5 \mathrm{a}$ & $63.9 \mathrm{a}$ \\
Khalas & $34.7 \mathrm{a}$ & $34.0 \mathrm{a}$ & $0.0 \mathrm{~b}$ & $69.0 \mathrm{a}$ \\
Sugai & $33.0 \mathrm{ab}$ & $33.6 \mathrm{a}$ & $1.3 \mathrm{~b}$ & $67.9 \mathrm{a}$ \\
Anbara & $30.7 \mathrm{~b}$ & $30.4 \mathrm{a}$ & $0.71 \mathrm{~b}$ & $61.8 \mathrm{a}$ \\
LSD (5\%) & 3.6 & 7.7 & 3.1 & 9.5 \\
\hline
\end{tabular}

Means in each column followed by the same letter(s) do not differ at $\mathrm{P} \leq$ 0.05 according to Duncan's multiple-range test. Values represent the mean \pm standard deviation $(\mathrm{n} \sim 5)$ for each cultivar.

Sukkary dates had significantly $(\mathrm{P} \leq 0.05)$ higher sucrose content than other cultivars and could be classified as disugar date. The other three cultivars (Khalas, Sugai and Anbara) had significantly ( $\mathrm{P} \leq 0.05$ ) higher levels of glucose and fructose, inalmost equal amounts, and thus were classified as two-sugar dates. Other international date standards such as the UNECE Standard DDP-08, Dates, 2009 Edition also classify dates according to their sugars levels. Results from this study are in agreement with those reported in a previous study [2] in which Tunisian dates were also classified according to sugar type. Results of sugar contents were also in agreement with those reported in a previous study of some Saudi date cultivars [6].

\subsection{Moisture Content of Dates}

Saudi standards for packaged dates do not suggest limits for moisture content. The Codex standards for dates suggest an upper limit of $26 \%$ moisture content for monosugar dates such as Sukkary dates and 30\% for two-sugar dates such as Khalas, Sugai and Anbara dates. However, there are no suggested minimum limits for moisture content of dates. From the data presented in Tables 6 and 7 it is clear that the moisture content of all fruits fell within the recommended maximum moisture levels. There were some significant differences in moisture contents and water activity for dates among the tested cultivars. For Sukkary and Anbara cultivars, medium and small size fruits had significantly ( $\mathrm{P} \leq 0.05)$ lower moisture contents than large fruits. This could be due to the higher surface area to volume ratio of these fruits, which result in higher moisture loss during the drying process. However, there were no significant differences in the water activity of the fruits. We suggest that water activity must also be considered in date standards due to its importance as an index of stability of date quality and microbial spoilage. Results of moisture content of dates samples were in agreement with those reported by some previous studies $[2,4,6]$. 
Table 6. Skin ratio and some physicochemical properties of unpressed-unpitted dates from four different cultivars.

\begin{tabular}{|c|c|c|c|c|c|}
\hline Date cultivar & Fruit size & $\%$ skin in $5 \mathrm{~g}$ & Moisture (\%) & Water activity (aw) & $\%$ insect damage \\
\hline \multirow{4}{*}{ Sukkary } & Large & 0 & 16.60 a & $0.601 \mathrm{a}$ & $0.0 \mathrm{a}$ \\
\hline & Medium & 0 & $15.23 \mathrm{~b}$ & 0.623 a & $0.0 \mathrm{a}$ \\
\hline & Small & 0 & $15.50 \mathrm{~b}$ & 0.612 a & $0.0 \mathrm{a}$ \\
\hline & LSD (5\%) & - & 0.73 & 0.072 & - \\
\hline \multirow{4}{*}{ Khalas } & Large & $10 \mathrm{a}$ & 15.43 & $0.563 \mathrm{a}$ & $11 \mathrm{~b}$ \\
\hline & Medium & $6 \mathrm{ab}$ & 14.60 a & $0.605 \mathrm{a}$ & $16 \mathrm{a}$ \\
\hline & Small & $4 \mathrm{~b}$ & 15.20 a & $0.578 \mathrm{a}$ & $6 \mathrm{c}$ \\
\hline & LSD (5\%) & 4.4 & 2.44 & 0.101 & 3.8 \\
\hline \multirow{4}{*}{ Sugai } & Large & $2 \mathrm{a}$ & $12.80 \mathrm{a}$ & 0.509 a & $0.0 \mathrm{a}$ \\
\hline & Medium & $0 \mathrm{~b}$ & 12.68 a & 0.449 a & $0.0 \mathrm{a}$ \\
\hline & Small & $0 \mathrm{~b}$ & $12.50 \mathrm{a}$ & $0.501 \mathrm{a}$ & $0.0 \mathrm{a}$ \\
\hline & LSD (5\%) & 1.3 & 3.4 & 0.072 & - \\
\hline \multirow{4}{*}{ Anbara } & Large & $7 \mathrm{a}$ & $14.20 \mathrm{a}$ & $0.472 \mathrm{a}$ & $1 \mathrm{a}$ \\
\hline & Medium & $3 \mathrm{~b}$ & $11.67 \mathrm{~b}$ & 0.459 a & $0.0 \mathrm{a}$ \\
\hline & Small & $0 \mathrm{c}$ & 12.80 & 0.417 a & $0.0 \mathrm{a}$ \\
\hline & LSD (5\%) & 1.6 & 1.75 & 0.072 & 1.3 \\
\hline
\end{tabular}

Means in each column followed by the same letter(s) do not differ at $\mathrm{P} \leq 0.05$ according to Duncan's multiple-range test. Values represent the mean \pm standard deviation $(\mathrm{n} \sim 5)$ for each fruit size.

Table 7. Skin ratio and some physicochemical properties of unpressed-pitted dates from four different cultivars.

\begin{tabular}{|c|c|c|c|c|c|}
\hline Date cultivar & Fruit size & $\%$ skin in $5 \mathrm{~g}$ & Moisture (\%) & Water activity (aw) & $\%$ insect damage \\
\hline \multirow{4}{*}{ Sukkary } & Large & 0 & $16.60 \mathrm{a}$ & $0.601 \mathrm{a}$ & $0.0 \mathrm{a}$ \\
\hline & Medium & 0 & $15.23 \mathrm{a}$ & $0.623 \mathrm{a}$ & $0.0 \mathrm{a}$ \\
\hline & Small & 0 & $15.50 \mathrm{a}$ & $0.612 \mathrm{a}$ & $0.0 \mathrm{a}$ \\
\hline & LSD (5\%) & - & 5.85 & 0.026 & - \\
\hline \multirow{4}{*}{ Khalas } & Large & $10 \mathrm{a}$ & $15.43 \mathrm{a}$ & $0.563 \mathrm{a}$ & $11 \mathrm{ab}$ \\
\hline & Medium & $6 \mathrm{ab}$ & $14.60 \mathrm{a}$ & $0.605 \mathrm{a}$ & $16 \mathrm{a}$ \\
\hline & Small & $4 \mathrm{~b}$ & $15.20 \mathrm{a}$ & $0.578 \mathrm{a}$ & $6 \mathrm{~b}$ \\
\hline & LSD (5\%) & 4.5 & 8.05 & 0.055 & 5.3 \\
\hline \multirow{4}{*}{ Sugai } & Large & $2 \mathrm{a}$ & $12.80 \mathrm{a}$ & 0.509 a & $0.0 \mathrm{a}$ \\
\hline & Medium & $0 \mathrm{a}$ & $12.68 \mathrm{a}$ & 0.449 a & $0.0 \mathrm{a}$ \\
\hline & Small & $0 \mathrm{a}$ & $12.50 \mathrm{a}$ & $0.501 \mathrm{a}$ & $0.0 \mathrm{a}$ \\
\hline & LSD (5\%) & 2.6 & 1.70 & 0.072 & - \\
\hline \multirow{4}{*}{ Anbara } & Large & 7 a & $14.20 \mathrm{a}$ & $0.472 \mathrm{a}$ & $1 \mathrm{a}$ \\
\hline & Medium & $3 b$ & $11.67 \mathrm{~b}$ & 0.459 a & $0.0 \mathrm{a}$ \\
\hline & Small & $0 \mathrm{~b}$ & $12.80 \mathrm{ab}$ & $0.417 \mathrm{a}$ & $0.0 \mathrm{a}$ \\
\hline & LSD (5\%) & 3.1 & 2.41 & 0.124 & 1.3 \\
\hline
\end{tabular}

Means in each column followed by the same letter(s) do not differ at $\mathrm{P} \leq 0.05$ according to Duncan's multiple-range test. Values represent the mean \pm standard deviation $(\mathrm{n} \sim 5)$ for each fruit size. 


\subsection{Weight, Length and Width of Dates and Stones}

Saudi standards for packaged dates do not suggest limits for fruit weight for dates, while the international Codex of date standards suggest minimum weights of $4.75 \mathrm{~g}$ and $4.0 \mathrm{~g}$ for unpitted and pitted date fruits, respectively. The results of this study indicated that all dates had weights higher than the international standards (Tables 8 and 9). Average fruit weights ranged from $7.59-20.14 \mathrm{~g}$ and $6.89-18.73 \mathrm{~g}$ for unpitted and pitted dates, respectively. There were significant differences $(P \leq 0.05)$ observed for fruits length and width as well as stone length and width between cultivars. Results for length and width of the studied dates are of great importance to support the efforts for designing machines for date grading.

\subsection{Number of Date Fruits in $500 \mathrm{~g}$ of Dates}

Number of date fruits per $500 \mathrm{~g}$ of date sample is considered as one of the selective indices for date classification according to fruit size in Saudi and international standards. According to these standards the number of date fruits should not exceed 110 and 90 fruits per $500 \mathrm{~g}$ for small size pitted and unpitted dates, respectively. For medium size fruits, the number should range from 90 -
110 fruits and from 80 - 90 fruits for pitted and unpitted dates, respectively. The corresponding numbers for large size dates are less than 90 for pitted and less than 80 for unpitted dates [30]. Results presented in Table 10 indicate that all fruit sizes (small, medium and Large) had less than 80 date fruits per $500 \mathrm{~g}$ of dates and thus could be classified as large dates according to the Saudi standards. The number of date fruits per $500 \mathrm{~g}$ of dates ranged from 31 for unpressed or pressed-pitted Anbara cultivar to 73 for unpressed-pitted Sugai cultivar. These results indicated that the Saudi dates are larger than dates of other countries and this may be of concern for international markets. Results also indicated that fruit size had significant $(P \leq 0.05)$ effect on the number of date per $500 \mathrm{~g}$ of dates. Unpressed-unpitted fruits had significantly $(P \leq 0.05)$ higher number of fruits than processed fruits. This indicates that the processing technique had a significant effect on the number of dates per $500 \mathrm{~g}$ of dates. These results were in agreement with those reported in a previous study on some Saudi date cultivars [6].

\subsection{Color Characteristics of Dates}

There is great variation in the color of dates from differ-

Table 8. Weight, length and width of fruits and stones of unpressed-unpitted dates from four different cultivars.

\begin{tabular}{|c|c|c|c|c|c|c|c|}
\hline Date cultivar & Fruit size & Fruit weight (g) & Fruit length $(\mathrm{cm})$ & Fruit width $(\mathbf{c m})$ & Stone weight (g) & Stone length $(\mathrm{cm})$ & Stone width (cm) \\
\hline \multirow{4}{*}{ Sukkary } & Large & 13.78 a & 3.3 a & $2.3 \mathrm{a}$ & $1.76 \mathrm{a}$ & $2.2 \mathrm{a}$ & $1.2 \mathrm{a}$ \\
\hline & Medium & $10.39 \mathrm{~b}$ & $3.1 \mathrm{~b}$ & $2.3 \mathrm{a}$ & $1.19 \mathrm{~b}$ & $1.9 \mathrm{~b}$ & $1.0 \mathrm{~b}$ \\
\hline & Small & $9.11 \mathrm{~b}$ & $2.8 \mathrm{c}$ & $2.1 \mathrm{~b}$ & $0.35 \mathrm{c}$ & $1.8 \mathrm{~b}$ & $1.0 \mathrm{~b}$ \\
\hline & LSD (5\%) & 1.54 & 0.17 & 0.14 & 0.40 & 0.2 & 0.1 \\
\hline \multirow{4}{*}{ Khalas } & Large & 11.90 a & 3.7 a & 1.9 a & $0.93 \mathrm{a}$ & $2.3 \mathrm{a}$ & $0.7 \mathrm{a}$ \\
\hline & Medium & $9.98 \mathrm{~b}$ & $3.5 \mathrm{~b}$ & $1.9 \mathrm{a}$ & $0.79 \mathrm{~b}$ & $2.1 \mathrm{~b}$ & $0.8 \mathrm{a}$ \\
\hline & Small & $7.60 \mathrm{c}$ & $3.3 \mathrm{c}$ & $1.8 \mathrm{a}$ & $0.71 \mathrm{~b}$ & $2.2 \mathrm{~b}$ & 0.7 a \\
\hline & LSD (5\%) & 1.55 & 0.12 & 3.5 & 0.12 & 0.14 & 1.9 \\
\hline \multirow{4}{*}{ Sugai } & Large & $14.41 \mathrm{a}$ & $4.0 \mathrm{a}$ & $2.2 \mathrm{a}$ & $0.84 \mathrm{a}$ & $2.2 \mathrm{a}$ & $0.9 \mathrm{a}$ \\
\hline & Medium & $11.26 \mathrm{~b}$ & $3.7 \mathrm{~b}$ & $2.1 \mathrm{a}$ & $0.75 \mathrm{~b}$ & $2.2 \mathrm{a}$ & 0.9 a \\
\hline & Small & $8.98 \mathrm{c}$ & $3.7 \mathrm{~b}$ & $2.0 \mathrm{~b}$ & $0.65 b$ & $2.2 \mathrm{a}$ & $0.6 \mathrm{~b}$ \\
\hline & LSD (5\%) & 1.02 & 0.1 & 0.12 & 0.1 & 3.4 & 0.1 \\
\hline \multirow{4}{*}{ Anbara } & Large & 20.14 a & $5.4 \mathrm{a}$ & $2.1 \mathrm{a}$ & $1.41 \mathrm{a}$ & $3.2 \mathrm{a}$ & $0.8 \mathrm{a}$ \\
\hline & Medium & $16.38 \mathrm{~b}$ & $4.8 \mathrm{a}$ & $2.2 \mathrm{a}$ & $0.79 \mathrm{~b}$ & $2.7 \mathrm{~b}$ & $0.6 \mathrm{c}$ \\
\hline & Small & $11.28 \mathrm{c}$ & $3.8 \mathrm{~b}$ & $1.8 \mathrm{~b}$ & $0.87 \mathrm{~b}$ & $2.5 \mathrm{~b}$ & $0.7 \mathrm{~b}$ \\
\hline & LSD (5\%) & 0.76 & 0.8 & 0.1 & 0.34 & 0.4 & 0.002 \\
\hline
\end{tabular}

Means in each column followed by the same letter(s) do not differ at $\mathrm{P} \leq 0.05$ according to Duncan's multiple-range test. Values represent the mean \pm standard deviation $(\mathrm{n} \sim 5)$ for each fruit size. 
Table 9. Weight and length and width of fruits and stones of pressed-pitted dates from four different cultivars.

\begin{tabular}{|c|c|c|c|c|c|c|c|}
\hline Date cultivar & Fruit size & Fruit weight (g) & Fruit length (cm) & Fruit width (cm) & Stone weight (g) & Stone length $(\mathrm{cm})$ & Stone width (cm) \\
\hline \multirow{4}{*}{ Sukkary } & Large & $12.82 \mathrm{a}$ & $3.30 \mathrm{a}$ & $2.33 \mathrm{a}$ & $1.77 \mathrm{a}$ & $2.20 \mathrm{a}$ & $1.20 \mathrm{a}$ \\
\hline & Medium & $9.40 \mathrm{~b}$ & $3.10 \mathrm{a}$ & $2.30 \mathrm{a}$ & $1.19 \mathrm{~b}$ & $1.80 \mathrm{~b}$ & $1.00 \mathrm{~b}$ \\
\hline & Small & $8.17 \mathrm{~b}$ & $2.80 \mathrm{~b}$ & $2.10 \mathrm{~b}$ & $1.05 \mathrm{~b}$ & $1.80 \mathrm{~b}$ & $1.00 \mathrm{~b}$ \\
\hline & LSD (5\%) & 1.59 & 0.2 & 0.1 & 0.2 & 0.2 & 0.1 \\
\hline \multirow{4}{*}{ Khalas } & Large & $11.90 \mathrm{a}$ & $3.71 \mathrm{a}$ & $1.90 \mathrm{a}$ & $0.93 \mathrm{a}$ & $2.30 \mathrm{a}$ & $0.70 \mathrm{a}$ \\
\hline & Medium & 10.97 a & $3.30 \mathrm{c}$ & $1.80 \mathrm{a}$ & $0.79 \mathrm{~b}$ & $2.10 \mathrm{c}$ & $0.80 \mathrm{a}$ \\
\hline & Small & $6.89 \mathrm{~b}$ & $3.50 \mathrm{~b}$ & $1.90 \mathrm{a}$ & $0.71 \mathrm{c}$ & $2.20 \mathrm{~b}$ & $0.70 \mathrm{a}$ \\
\hline & LSD (5\%) & 1.20 & 0.17 & 1.80 & 0.07 & 0.002 & 1.09 \\
\hline \multirow{4}{*}{ Sugai } & Large & 13.57 a & $4.00 \mathrm{a}$ & $2.20 \mathrm{a}$ & $0.84 \mathrm{a}$ & $2.20 \mathrm{a}$ & $0.90 \mathrm{a}$ \\
\hline & Medium & $10.51 \mathrm{~b}$ & $3.70 \mathrm{~b}$ & $2.10 \mathrm{a}$ & $0.75 \mathrm{ab}$ & $2.20 \mathrm{a}$ & $0.90 \mathrm{a}$ \\
\hline & Small & $8.33 \mathrm{c}$ & $3.70 \mathrm{~b}$ & $2.00 \mathrm{a}$ & $0.65 \mathrm{~b}$ & $2.20 \mathrm{a}$ & $0.60 \mathrm{~b}$ \\
\hline & LSD (5\%) & 2.11 & 0.12 & 1.18 & 0.10 & 1.15 & 0.10 \\
\hline \multirow{4}{*}{ Anbara } & Large & $19.46 \mathrm{a}$ & $5.41 \mathrm{a}$ & $2.43 \mathrm{a}$ & $1.203 \mathrm{a}$ & $3.00 \mathrm{a}$ & $0.81 \mathrm{a}$ \\
\hline & Medium & $15.96 \mathrm{~b}$ & $4.61 \mathrm{~b}$ & $2.29 \mathrm{a}$ & $0.795 \mathrm{~b}$ & $2.62 \mathrm{~b}$ & $0.69 \mathrm{~b}$ \\
\hline & Small & $11.14 \mathrm{c}$ & $4.04 \mathrm{c}$ & $1.81 \mathrm{~b}$ & $0.700 \mathrm{~b}$ & $2.41 \mathrm{c}$ & $0.70 \mathrm{~b}$ \\
\hline & LSD (5\%) & 3.06 & 0.20 & 0.34 & 0.17 & 0.12 & 0.007 \\
\hline
\end{tabular}

Means in each column followed by the same letter(s) do not differ at $\mathrm{P} \leq 0.05$ according to Duncan's multiple-range test. Values represent the mean \pm standard deviation $(\mathrm{n} \sim 5)$ for each fruit size.

Table 10. Cultivar differences in terms of number of date fruits on $500 \mathrm{~g}$ of dates.

\begin{tabular}{|c|c|c|c|c|}
\hline Date cultivar & Fruit size & Unpressed-unpitted & Pressed-pitted & Unpressed-pitted \\
\hline \multirow{4}{*}{ Sukkary } & Large & 39 c & $35 \mathrm{c}$ & $50 \mathrm{~b}$ \\
\hline & Medium & $44 \mathrm{~b}$ & $42 \mathrm{~b}$ & $51 \mathrm{~b}$ \\
\hline & Small & $50 \mathrm{a}$ & 47 a & 56 a \\
\hline & LSD (5\%) & 3.5 & 5.0 & 3.5 \\
\hline \multirow{4}{*}{ Khalas } & Large & $50 \mathrm{c}$ & $50 \mathrm{~b}$ & $56 c$ \\
\hline & Medium & $55 \mathrm{~b}$ & $52 \mathrm{~b}$ & $62 \mathrm{~b}$ \\
\hline & Small & 65 a & 59 a & $71 \mathrm{a}$ \\
\hline & LSD (5\%) & 3.5 & 2.6 & 3.5 \\
\hline \multirow{4}{*}{ Sugai } & Large & $37 \mathrm{c}$ & $36 \mathrm{c}$ & $45 \mathrm{c}$ \\
\hline & Medium & $52 \mathrm{~b}$ & $47 \mathrm{~b}$ & $55 \mathrm{~b}$ \\
\hline & Small & 73 a & 68 a & $75 \mathrm{a}$ \\
\hline & LSD (5\%) & 4.0 & 3.6 & 3.5 \\
\hline \multirow{4}{*}{ Anbara } & Large & $32 \mathrm{~b}$ & 32 a & $34 \mathrm{~b}$ \\
\hline & Medium & $35 \mathrm{ab}$ & 34 a & $35 \mathrm{~b}$ \\
\hline & Small & 39 a & 34 a & $42 \mathrm{a}$ \\
\hline & LSD (5\%) & 5.0 & 3.5 & 3.2 \\
\hline
\end{tabular}

Means in each column followed by the same letter(s) do not differ at $\mathrm{P} \leq 0.05$ according to Duncan's multiple-range test. Values represent the mean \pm standard deviation $(\mathrm{n} \sim 5)$ for each fruit size. 
Table 11. Color characteristics of unpressed-unpitted dates from four different cultivars.

\begin{tabular}{|c|c|c|c|c|c|c|}
\hline Date cultivar & Fruit size & $\mathbf{a}$ & b & $\mathbf{L}$ & $\mathrm{C} \%{ }^{*}$ & H\% ${ }^{* *}$ \\
\hline \multirow{4}{*}{ Sukkary } & Large & 34.75 a & 19.75 a & 62.84 a & 39.97 a & $52.99 \mathrm{a}$ \\
\hline & Medium & $28.21 \mathrm{~b}$ & 22.04 a & 61.28 a & 35.80 a & $48.53 \mathrm{a}$ \\
\hline & Small & 32.73 a & 19.43 a & 66.84 a & 38.06 a & $52.39 \mathrm{a}$ \\
\hline & LSD (5\%) & 4.55 & 2.99 & 7.40 & 5.58 & 4.36 \\
\hline \multirow{4}{*}{ Khalas } & Large & 9.67 a & 9.48 a & 18.65 a & 13.54 a & $45.28 \mathrm{a}$ \\
\hline & Medium & 10.06 a & $9.03 \mathrm{a}$ & 16.14 a & $13.52 \mathrm{a}$ & $46.55 \mathrm{a}$ \\
\hline & Small & $11.50 \mathrm{a}$ & $7.46 \mathrm{a}$ & 21.83 a & $13.71 \mathrm{a}$ & $51.15 \mathrm{a}$ \\
\hline & LSD (5\%) & 2.50 & 4.55 & 6.64 & 5.16 & 6.96 \\
\hline \multirow{4}{*}{ Sugai } & Large & 21.98 a & 20.12 a & 49.09 a & 29.80 a & $46.27 \mathrm{a}$ \\
\hline & Medium & 20.79 a & 20.18 a & 48.57 a & 28.97 a & $45.43 \mathrm{a}$ \\
\hline & Small & 20.94 a & 22.78 a & $45.61 \mathrm{a}$ & 30.94 a & $43.79 \mathrm{a}$ \\
\hline & LSD (5\%) & 6.58 & 6.74 & 9.62 & 5.60 & 3.69 \\
\hline \multirow{4}{*}{ Anbara } & Large & $2.11 \mathrm{~b}$ & $5.53 \mathrm{c}$ & 38.40 a & $11.94 \mathrm{~b}$ & $40.30 \mathrm{a}$ \\
\hline & Medium & $4.07 \mathrm{a}$ & 8.96 a & 37.60 a & 13.85 a & $40.89 a$ \\
\hline & Small & $2.64 \mathrm{ab}$ & $6.95 \mathrm{~b}$ & 38.34 a & 13.19 a & $36.69 \mathrm{~b}$ \\
\hline & LSD (5\%) & 1.90 & 1.27 & 4.30 & 1.13 & 3.26 \\
\hline
\end{tabular}

"Chroma $(C)=\left(a^{2}+b^{2}\right)^{0.5} \%,{ }^{* *}$ Hue angle $(H)=\tan ^{-1}(b / a)^{0.5}$. Means in each column followed by the same letter(s) do not differ at $\mathrm{P} \leq 0.05$ according to Duncan's multiple-range test. Values represent the mean \pm standard deviation $(n \sim 5)$ for each fruit size.

ent date cultivars in Saudi Arabia. Saudi and international standards do not suggest any limits for dates color. However, American standards for dates recommended a good homogeneity in date color, requiring that light amber colored dates must present no more than $5 \%$ of dark colored dates and also that dark colored dates present no more than $5 \%$ of light colored dates [31]. In this study, color characteristics of the 4 different cultivars were estimated using Hunterlab technique which measure values of L (lightness), a (red/green) and b (yellow/ blue) as shown in Table 11. Date cultivar had a significant effect on fruit color. Anbara dates were significantly darker $(\mathrm{P} \leq 0.05)$ than other cultivars. Fruit size and the processing technique had no significant effect on fruit color. This study suggests that color characteristics for date fruits must be taken into consideration in packaged standards for dates. In addition color characteristics may be of useful when grading dates according to their colors. These results are in agreement with the findings from previous studies [2,4].

\section{Conclusion}

In light of the results from this study, it could be concluded that some important quality parameters were measured in the tested dates, the results will provide new information required to modify existing dates standards. Further assessment of commercial applications of suggested quality indices is necessary. A comparative analysis of microbiological quality and physicochemical properties at the farm level, as well as a comprehensive investigation of current guidelines on dates quality, are required in order to review the important quality criteria of dates standards.

\section{Acknowledgements}

The authors would like to thank the Date Palm Research Center of Excellence, King Faisal University, Alahsa, Saudi Arabia, for financial support to carry out this work.

\section{REFERENCES}

[1] W. H. Barreveld, "Date palm products," Food and Agriculture Organization of the United Nations, Rome, 1993, $216 \mathrm{p}$.

[2] A. Mrabet, A. Ferchichi, N. Chaira, B. S. Mohamed, M. Baaziz and T. M. Penny, "Physico-Chemical Characteristics and Total Quality of Date Palm Varieties Grown in the Southern of Tunisia,” Pakistan Journal of Biological Sciences, Vol. 11, No. 7, 2008, pp. 1003-1008. 
http://dx.doi.org/10.3923/pjbs.2008.1003.1008

[3] S. AlHooti, J. S. Sidhu, H. Al-Amiri, J. Al-Otaibi and H. Qabazard, "Extension of the Shelf Life of Two UAE Date Fruit Varieties at Khalaal and Rutab Stages of Maturity," Arab Gulf Journal of Scientific Research, Vol. 15, No. 1, 1997, pp. 99-110.

[4] A. Hasnaoui, M. A. Elhoumaizi, A. Hakkou, B. Wathelet and M. Sindic, "Physico-Chemical Characterization, Classification and Quality Evaluation of Date Palm Fruits of Some Moroccan Cultivars," Journal of Scientific Research, Vol. 3, No. 10, 2011, pp. 139-149.

[5] C. Borchani, S. Besbes, C. Blecker, M. Masmoudi, R. Baati and H. Attia, "Chemical Properties of 11 Date Cultivars and Their Corresponding Fiber Extracts," African Journal of Biotechnology, Vol. 9, No. 26, 2010, pp. 40964105.

[6] A. I. Al-Abdoulhadi, S. Al-Ali, K. Khurshid, F. Al-Shryda, A. M. Al-Jabr and A. Ben Abdallah, “Assessing Fruit Characteristics to Standardize Quality Norms in Date Cultivars of Saudi Arabia,” Indian Journal of Science and Technology, Vol. 4, No. 10, 2011, pp. 1262-1266.

[7] M. S. Rahman and S. A. Al-Farsi, "Instrumental Texture Profile Analysis (TPA) of Date Flesh as a Function of Moisture Content," Journal of Food Engineering, Vol. 66, No. 4, 2005, pp. 505-511. http://dx.doi.org/10.1016/j.jfoodeng.2004.04.022

[8] J. R. Piggott, "Design Questions in Sensory and Consumer Science,” Food Quality and Preference, Vol. 6, No. 4, 1995, pp. 217-220. http://dx.doi.org/10.1016/0950-3293(95)00016-X

[9] R. Wills, B. McGlasson, D. Graham and D. Joyce, "Post Harvest: An Introduction to the Physiology and Handling of Fruits, Vegetables and Ornamentals," 4th Edition, University of New South Wales Press Ltd, Australia, 1998, $262 \mathrm{p}$.

[10] S. A. Saleem, “Aspects of Ripening of Dhakki Dates (Phoenix dactylifera L.) and Post Harvest Stability Employing Hurdle Technology,” PhD Dissertation, Gomal University, Pakistan, 2005, 192 p.

[11] AOAC, “Official Methods of Analysis," 15th Edition, Association of Official Analytical Chemists, Washington DC, 1995.

[12] S. M. Aleid, M. I. El-Shaarawy, A. S. Mesallam and S. I. Al-Jendan, "Chemical Composition and Nutritive Value of Some Sugar and Date Syrups,” Journal of Agricultural Research, Vol. 24, 1999, pp. 577-587.

[13] S. M. Aleid, A. R. Barber, M. Rettke, N. Leo, W. A. Alsenaien and A. A. Sallam, "Utilization of Modified Atmosphere Packaging to Extend the Shelf Life of Khalas Fresh Dates," International Journal of Food Science \& Technology, Vol. 47, No. 7, 2012, pp. 1518-1525. http://dx.doi.org/10.1111/j.1365-2621.2012.03000.x

[14] R. M. Atlas, "Handbook of Microbiological Media," 3rd Edition, CRC Press, Boca Raton, 2004, 2051 p. http://dx.doi.org/10.1201/9781420039726

[15] R. G. Steel and J. H. Torrie, "Principles and Procedures of Statistics,” 2nd Edition, McGraw Hill Book Co., NY,
1980, 633 p.

[16] A. Nussinovitch, B. Rosen, H. Salik and I. J. Kopelman, "Effect of Heating Media on the Microbiology and Shelf Life of Heat Pasteurized Soft Dates," Lebensmittel-Wissenschaft und Technologie, Vol. 22, No. 5, 1989, pp. 245247.

[17] K. E. Aidoo, R. F. Tester, J. E. Morrison and D. MacFarlane, "The Composition and Microbial Quality of PrePacked Dates Purchased in Greater Glasgow,” International Journal of Food Science \& Technology, Vol. 31, No. 5, 1996, pp. 433-438. http://dx.doi.org/10.1046/j.1365-2621.1996.00360.x

[18] A. A. Kader, "Recommendation for Maintaining Postharvest Quality,” University of California, Davis, 2007. http://postharvest.ucdavis.edu/produce/fruit/dates.shtm

[19] Public Health Laboratory Services (PHLS), "Provisional Microbiological Guidelines for Some Ready-to-Eat Foods Sampled at Point of Sale, Notes for PHLS Food Examiners,” PHLS Microbiology Digest, Vol. 9, 1992, pp. 98-99.

[20] Public Health Laboratory Services (PHLS), "Microbiological Guidelines for Some Ready-to-Eat Foods Sampled at the Point of Sale: An Expert Opinion from the PHLS," PHLS Microbiology Digest, Vol. 13, 1996, pp. 41-43.

[21] R. J. Gilbert, "Microbiological Guidelines for Some Readyto-Eat Foods Sampled at the Point of Sale: An Expert Opinion from the Public Health Laboratory Service (PHLS)," PHLS Microbiology Digest, Vol. 13, 1996, pp. 41-43.

[22] A. H. Abu-Zinada and M. I. Ali, "Fungi Associated with Dates in Saudi Arabia,” Journal of Food Protection, Vol. 45, No. 9, 1982, pp. 842-844.

[23] M. T. Brandl, "Fitness of Human Enteric Pathogens on Plants and Implications for Food Safety," Annual Review of Phytopathology, Vol. 44, 2006, pp. 367-392. http://dx.doi.org/10.1146/annurev.phyto.44.070505.14335 $\underline{9}$

[24] A. J. Hamilton, F. Stagnitti, R. Premier, A. M. Boland and G. Hale, "Quantitative Microbial Risk Assessment Models for Consumption of Raw Vegetables Irrigated with Reclaimed Water," Applied and Environmental Microbiology, Vol. 72, No. 5, 2006, pp. 3284-3290. http://dx.doi.org/10.1128/AEM.72.5.3284-3290.2006

[25] H. L. Tyler and E. W. Triplett, "Plants as a Habitat for Beneficial and/or Human Pathogenic Bacteria,” Annual Review of Phytopathology, Vol. 46, 2008, pp. 53-63. http://dx.doi.org/10.1146/annurev.phyto.011708.103102

[26] M. R. El-Sherbeeny, M. F. Saddik and F. L. Bryan, "Microbial Profiles of Foods Served by Street Vendors in Egypt,” International Journal of Food Microbiology, Vol. 2, No. 6, 1985, pp. 355-364. http://dx.doi.org/10.1016/0168-1605(85)90026-1

[27] Saudi Standards, "Metrology and Quality Organization (SASO)," Microbial Limits for Food Stuffs (in Arabic), Part 1," Saudi Arabia Standards Organization, 1998, 26 p.

[28] M. P. Doyle and M. C. Erickson, "Closing the Door on the Fecal Coliform Assay,” Microbe, Vol. 1, No. 4, 2006, pp. 162-163. 
[29] Woolworths Quality Assurance Standard (WQAS), “Guidelines,” Version 6, 2009.

[30] Codex, "Codex Standard for Dates," CODEX STAN 1431985, Codex Alimentarius, 1985, 6 p.
[31] “United States Standards for Grades of Dates," US Department of Agriculture, Washington DC, 20090-6456, 1955, $15 \mathrm{p}$. 